\title{
TIME FLIES
}

\section{The catch of a lifetime.}

BY CARIE JUETTNER

“D

ang! I almost had it."

"No, you didn't. You were a mile away."

"Was not. It was a good one too. It was tiny."

"That's a myth, you know," I said, swiping at a mediumsized green one with my baseball cap. "Size doesn't matter."

"Yeah it does, Kat." Jeremy put his net away and got out a pair of chopsticks. I rolled my eyes. "The small ones are always worth more. Haven't you ever noticed that the big slow ones that are so easy to catch are never worth more than an hour or two?"

"So? I'm starting to think there are no valuable ones anymore. I think they went extinct or something."

"No, they're out there. My friend Jon caught a 17-year one once!"

"Oh yeah? Did you actually see it?" I swiped my foot through the tall grass, trying to stir something up.

"No, but I believe him."

"Seventeen years, huh? So does Jon look different now?"

A small iridescent blue one flew by. Jeremy made a flailing jab at it and missed. "No. It got away before he could swallow it."

"Pshh. Then he was lying." I made an attempt at the blue one, but it was already out of my reach. "There's nothing bigger than a year out there anymore. Sometimes I think there's nothing bigger than a week."

"If you really think that, then why do you even catch?"

I shrugged. "Every little bit helps."

We were quiet for a while. A thick-bodied brown buzzer lifted clumsily out of the grass and I grabbed it without even using my cap. I flipped it over. Three hours. Turning my back to Jeremy, I popped the whole thing in my

$\rightarrow$ NATURE.COM Follow Futures: 3. @NatureFutures f go.nature.com/mtoodm mouth at once. I bit down and the buzzing stopped as the earthy metallic taste flooded my tongue. I swallowed and waited, eyes closed, for the sensation I knew would come. I had to concentrate or I would miss it. A quick burst of energy and warmth passed through me, and then it was gone. I opened my eyes.

"You know," Jeremy said, "my grandfather hated catching. He wouldn't let me do it when he was around. He said we should be happy with the time we're born with."

I scoffed. "And where is he now?"

"He's dead."

I nodded. It was starting to get dark. There'd be more coming soon, but they'd be harder to see.

"How long do you think you'll do it?" I asked.

"Do what?"

"Catch."

Jeremy shrugged. "Not long. I just want to build up little more, you know? Bank it. Then I'll stop. I mean, I'm not going to do it for ever."

"Me neither." I knew it was rude to ask, but I couldn't help myself. "How much do you have? You know, in the bank?"
Jeremy examined his shoes. "A good amount. I'm comfortable."

I nodded.

"Yeah," he said. "Just one more 8 good catch, and I'll hang up my

7 net." He smiled at me. "And 7 i my chopsticks."

Z I smiled back.

I heard a high-pitched

buzzing behind me. I turned around and saw a minuscule flyer heading right for us. I pulled my cap back, but Jeremy was faster. He dropped his chopsticks and clasped his bare hands around it, trapping it inside. "I got it!" he yelled. "I actually got it!" He whooped and jumped up and down. "It's the smallest one I've ever seen!"

"So look at it already. What is it?" I crossed my arms to keep them from shaking. What if the myth was true after all?

Jeremy moved his hands carefully until he had the tiny creature pinned firmly between his fingers. $\mathrm{He}$ flipped it over and peered at the underside. For just a moment, his face fell. Then his smile was back. He popped the thing in his mouth, swallowed loudly and stood still for a long time. I let him have his moment, even though it was killing me to wait. What was it? Ten years? Twenty? Finally, he let out a deep sigh and looked at me.

"How much?" I asked.

"Six."

"Six years?"

He nodded. My arms relaxed a little.

“That's a pretty good catch," I said.

He nodded again, smiling slightly. "Yeah."

"So," I said, "since you're not going to be needing that net...?" I held my hand out towards him.

A hum filled the air as several large flyers and a few medium-sized ones emerged from the grass. Jeremy shuffled his feet, his fingers gripping the net. "Actually ... I think ... maybe I'll try for just one more."

Carie Juettner is a writer in Austin, Texas. Her fiction has appeared in Hello Horror, Dark Moon Digest, Microhorror and Writers Weekly, among other places. Follow her blog at www.cariejuettner.com. 